\title{
The Interaction of Agonists and Noncompetitive Antagonists at the Excitatory Amino Acid Receptors in Rat Retinal Ganglion Cells in vitro
}

\author{
Andreas Karschin, ${ }^{1}$ Elias Aizenman, ${ }^{2}$ and Stuart A. Lipton ${ }^{2}$ \\ 'Max-Planck-Institut für Hirnforschung, 6000 Frankfurt/M., FRG, and 'Division of Neuroscience, The Children's Hospital, \\ and Department of Neurology, Harvard Medical School, Boston, Massachusetts 02115
}

The pharmacological properties of the interaction between the excitatory amino acid (EAA) analogs kainate and $\mathrm{N}$-methyl-D-aspartate (NMDA) have been examined on the isolated rat retinal ganglion cell preparation. In addition, we have studied the effects on this interaction of 2 noncompetitive NMDA antagonists, the dissociative anesthetic phencyclidine (PCP) and the anticonvulsant MK-801. Electrophysiological measurements were performed with the whole-cell patch-clamp technique on cultured ganglion cells that had been back-labeled with a fluorescent dye. Whereas only $69 \%$ of the cells showed responses to NMDA (in the absence of extracellular $\mathbf{M g}^{2+}$ ), every ganglion cell responded to kainate under the same conditions. When a given cell was voltage-clamped at $-60 \mathrm{mV}$, the large inward currents elicited by $125 \mu \mathrm{M}$ kainate generally exceeded the responses evoked by $200 \mu \mathrm{M}$ NMDA, when present, by 1 or 2 orders of magnitude. There was a poor correlation between the magnitudes of the currents produced by both agonists for the population of cells tested. Furthermore, NMDA proved to be an antagonist for the kainate receptor binding site.

Without influencing the kainate-activated currents, PCP (75 $\mu \mathrm{M})$ and MK-801 $(20 \mu \mathrm{M})$ completely and reversibly blocked the responses evoked by NMDA $(200 \mu \mathrm{M})$, independent of the membrane holding potential. The degree of block produced by a submaximal concentration of either antagonist was accentuated by increasing the concentration of NMDA.

The independence of NMDA and kainate currents was examined. In the presence of NMDA and PCP (or MK-801), kainate-induced responses were comparable in amplitude to those generated by the application of kainate and NMDA together. Thus, kainate continued to produce an increase in membrane conductance at a time when NMDA-activated currents were blocked by either antagonist. The NMDA antagonism of kainate-induced currents was shown to be constant and independent of PCP or MK-801. Our results suggest that the 2 EAA analogs might not share a common ionophore, but rather activate separate receptor-ion channel complexes in rat retinal ganglion cell membranes.

\footnotetext{
Received Aug. 3, 1987; revised Nov. 30, 1987; accepted Dec. 3, 1987.

We would like to thank Drs. M. Frosch and P. Rosenberg for helpful discussions, Dr. H. Wässle for encouragement and support, and B. Cahoon and P. Kaiser for technical assistance. This work was supported by the Max-Planck-Gesellschaft FRG. (A.K.) and NIH Grants NS07264 (E.A.), EY05477 (S.A.L.), and NS00879 (S.A.L.).

Correspondence should be addressed to Elias Aizenman, Ph.D., Division of Neuroscience, The Children's Hospital-G4, 300 Longwood Ave., Boston, MA 02115.

Copyright (C) 1988 Society for Neuroscience $0270-6474 / 88 / 082895-12 \$ 02.00 / 0$
}

The excitatory amino acids (EAAs) L-glutamate and L-aspartate, or a related substance, are thought to be the primary neurotransmitters that mediate fast synaptic transmission in the vertebrate CNS (Johnson, 1972; Fonnum, 1984; Foster and Fagg, 1984). The receptors activated by these transmitters are subdivided into 3 major types according to their affinities for the glutamate analogs quisqualate, kainate, and $N$-methyl-D-aspartate (NMDA; Watkins and Evans, 1981). In the retina, as part of the CNS, EAAs have been suggested to act as neurotransmitters both in the outer and inner plexiform layers (Murakami et al., 1975; Bloomfield and Dowling, 1985a, b; reviewed by Miller and Slaughter, 1986). A fourth type of EAA receptor, selective for 2-amino-4-phosphonobutyrate (APB), is apparently located only on the bipolar cells of the retina (Miller and Slaughter, 1986).

In the inner plexiform layer, where ganglion cells are fed postsynaptically from both bipolar and amacrine cells, evidence for EAA neurotransmission has been obtained from both immunocytochemical and electrophysiological studies (Berger et al., 1977; Ikeda and Sheardown, 1982). Kainate, quisqualate, and NMDA have been shown to depolarize all amacrines and most ganglion cells in situ in the amphibian retina (Slaughter and Miller, 1983). In a previous study (Aizenman et al., 1988), we reported that ganglion cells dissociated from the rat retina respond to EAA analogs. These responses are comparable to those observed in other mammalian central neurons with respect to current-voltage characteristics and pharmacological susceptibilities. It was found that while all cells responded to kainate, only a fraction of the cells tested responded to NMDA $(68 \%)$ and quisqualate $(50 \%)$. Interestingly, horizontal cells, one class of interneurons that receive input from photoreceptors in the outer plexiform layer, have been shown both in situ and in cultures to be depolarized by glutamate, quisqualate, and kainate, but not by NMDA (Lasater and Dowling, 1982; Ariel et al., 1984; Ishida et al., 1984; but see O'Dell and Christensen, 1986a). Since the different types of EAA receptors seem to be expressed in some cells, but not in others, further investigation of the receptor-channel complexes present in retinal ganglion cells may provide basic information regarding the mechanism of excitatory neurotransmission in the inner retina.

A model for glutamatergic excitation has recently been proposed for hippocampal and cerebellar neurons; in this model, various glutamate analogs open a common receptor-associated ionophore to several distinct subconductance states (Cull-Candy and Usowicz, 1987; Jahr and Stevens, 1987). In the present report, we evaluate this model by examining the properties of the NMDA and kainate interaction at the putative receptor sites 
of our preparation. In addition, we have investigated the effects of specific noncompetitive ${ }^{1}$ antagonists on this interaction in an attempt to elucidate the principles of the binding site-channel coupling that leads to excitatory neurotransmission in retinal ganglion cells.

A possible distinction between the channels activated by kainate and NMDA receptors is of potential clinical importance, since these 2 agonists have been shown to have disparate actions. For example, excessive stimulation of NMDA receptors has been implicated in the pathophysiology of neuronal degeneration caused by a variety of conditions, such as ischemia (Rothman and Olney, 1987). Therefore, antagonists would prove clinicially useful if they could inhibit selectively and more effectively as the concentration of NMDA increased (e.g., by blocking specific ionic channels in an agonist-dependent manner). We report here such an effect of the antagonist MK-801.

Part of this work has appeared previously in abstract form (Karschin et al., 1987).

\section{Materials and Methods}

Identification, dissociation, and culture of cells. Retinal ganglion cells were specifically labeled in vivo by retrograde transport of the fluorescent dye granular blue (Leifer et al., 1984), which both stains the nucleus and cytoplasm of the cells and has been shown not to adversely affect the cells under electrophysiological study (Lipton and Tauck, 1987). A suspension of the dye in saline was injected into the ganglion cells projection site, the superior colliculus, of pigmented Long-Evans 5-dold rats (Charles River) under cryoanesthesia, as previously reported (Leifer et al., 1984).

Details of the dissociation procedure and conditions of the tissue culture have been described in preceding papers (Lipton and Tauck, 1987; Lipton et al., 1987; Aizenman et al., 1988). Briefly, the animals were killed $3 \mathrm{~d}$ after dye injection by cervical dislocation, enucleated, and the retinas dissected. Following digestion in a papain enzyme solution, retinas were mechanically dispersed by gentle trituration. The isolated cells were plated onto poly-L-lysine-coated glass coverslips in tissue culture dishes and incubated in Eagle's minimal essential media (Gibco) with methylcellulose $(0.7 \% \mathrm{wt} / \mathrm{vol})$, glutamine ( $2 \mathrm{~mm})$, glucose $(16 \mathrm{~mm})$, and fetal calf serum $(10 \% \mathrm{vol} / \mathrm{vol})$ for at least $6 \mathrm{hr}$.

The freshly dissociated ganglion cells, identified by their blue fluorescence, usually appeared to be $10-25 \mu \mathrm{m}$ in diameter and retained $1-$ 4 primary stout processes up to $60 \mu \mathrm{m}$ in length, but lacked the extensive dendritic arborization typical for retinal ganglion cells in situ. By the time electrophysiological recordings were made (6-24 hr following plating), these processes had retracted into the cell soma, producing cells of spherical shape, approximately $10 \%$ of which remained solitary, with no identifiable connections to other cells. With increasing time in culture (greater than $24 \mathrm{hr}$ ), ganglion cells were observed to regrow numerous short spiny processes and infrequently displayed elongated neurite outgrowth with the appearance of obvious growth cones.

Electrophysiological recordings. The recording chamber consisted of a stainless steel insert placed into the tissue culture dishes, which limited the fluid volume to approximately $100 \mu$ l. The cells were continuously superfused at a rate of $0.8 \mathrm{ml} / \mathrm{min}$ with a bath solution containing a $\mathrm{Na}$ ' saline based on Hanks' balanced salts (in mM): $\mathrm{NaCl}, 138 ; \mathrm{NaHCO}_{3}$, $1 ; \mathrm{Na}_{2} \mathrm{HPO}_{4}, 0.34 ; \mathrm{KCl}, 5.36 ; \mathrm{KH}_{2} \mathrm{PO}_{4}, 0.44 ; \mathrm{CaCl}_{2}, 2.5 ; \mathrm{HEPES}-\mathrm{NaOH}$, 5 ; glucose, $22.2 ; \mathrm{pH} 7.2$ with phenol red indicator $(0.001 \% \mathrm{vol} / \mathrm{vol})$ Since NMDA-evoked currents are subject to voltage-dependent block by extracellular $\mathrm{Mg}^{2+}$ (Ault et al., 1980; Nowak et al., 1984; Mayer and Westbrook, 1985), no magnesium salts were added to the bath solution. The superfusion solution was temperature-controlled to $32-35^{\circ} \mathrm{C}$ by the heated stage of an inverted microscope equipped with phase-contrast

\footnotetext{
'Within this report, the term "noncompetitive" is used to define the action of an antagonist that acts at a site different from that of the agonist (in contradistinction to a competitive antagonist). In the experiments described, noncompetitive antagonism includes "uncompetitive" inhibition, which is the term used when antagonism is continent upon prior activation of the receptor by the agonist.
}

optics (IM35; Zeiss, FRG). When UV light was used to identify rat retinal ganglion cells under high magnification $(500 \times)$, exposure times were kept short in order to prevent damage to the cells by this irradiation.

The whole-cell configuration of the patch-clamp method (Hamill et al., 1981) was used to record the macroscopic membrane currents of the ganglion cells under voltage-clamp conditions. Patch electrodes were pulled from soft glass (hematocrit capillaries) in a 2-stage process on a BB-CH puller (Mecanex, Geneva, Switzerland), coated with Sylgard and fire-polished on a microforge. The micropipettes had resistances of 4$8 \mathrm{M} \Omega$ when measured prior to cell contact with a conventional internal solution of $\mathrm{Na}^{+}$or $\mathrm{K}^{+}$saline. During whole-cell recording, the input resistance of the cell was generally from $850 \mathrm{M} \Omega$ to $5 \mathrm{G} \Omega$. The internal solution usually consisted of (in $\mathrm{mM}$ ) $\mathrm{CsCl}, 120 ; \mathrm{TEACl}, 20 ; \mathrm{MgCl}_{2}, 1$; $\mathrm{CaCl}_{2}, 1$; EGTA, 1.5; HEPES-NaOH, 10; pH 7.2. Cesium and tetraethylammonium (TEA) were added to suppress potassium currents; holding potentials maintained for several tens of seconds prior to drug application abolished voltage-dependent transient sodium and calcium conduclances. The indifferent reference electrode was an $\mathrm{Ag}-\mathrm{AgCl}$ wire connected to the bath solution via an agarose bridge; leakage currents, liquid junction potentials, and series resistance were corrected as described in renwick et al. (1982).

Currents were recorded with an EPC-7 patch-clamp amplifier (List Electronics, FRG), digitized with a 12 -bit, $125 \mathrm{kHz}$ analog-to-digital converter (Model DT2782 DMA; Data Translation, Marlborough, MA), and viewed on a Hewlett-Packard digital display (Model 1345A). The sampling rate was set at $1-2.5 \mathrm{kHz}$. and the signals filtered at $500 \mathrm{kHz}$. (Model 4302 with a Bessel cutoff frequency of $48 \mathrm{~dB} /$ octave, Ithaco, Ithaca, NY). The holding and command potentials were generated by a PDP-1 1/23 computer (Digital Equipment, Maynard, M $\Lambda$ ) interfaced with a digital-to-analog converter (Cheshire Data, Hamden, CT). Data were stored on a 30-megabyte Winchester disk (Model 880; Data Systems Design, San Jose, CA) and transferred to streaming tape (Model LSI-50; Alloy Computer Products, Marlborough, MA).

Drugs and drug application. Test substances were applied to the retinal ganglion cells by pressure ejection from fine micropipettes having a tip diameter of $5-10 \mu \mathrm{m}$ and positioned $20-40 \mu \mathrm{m}$ from the cell bodies. Up to 4 micropipettes were arranged in a half-circle around the cell under study and kept apart to minimize possible diffusion of drugs from one pipette in to another. When the interaction of EAA receptor agonists and antagonists was tested, the drugs were applied in combination from the same pipette. This microperfusion technique was automatically controlled by the computer and generated reproducible current responses, although the exact final concentration of the drugs tested at the cell membrane was not known (the values listed in Results represent the drug concentrations in the application pipettes). Differences in delay or rise lime of the recorded whole-cell response following a pressure pulse were mainly due to the position of the pipettes, the tip diameter, and the pressure applied. Even if these differences reflected changes in the characteristics of receptor binding or channel opening kinetics, this would likely go undetected on the slow time scale we used and thus was not the subject of study.

Kainate and phencyclidine- $\mathrm{D}_{5}$-hydrochloride (PCP) were obtained from Sigma, NMDA from Cambridge Research Biomedicals (UK), MK-801 ([+])-5-methyl-10,11-dihydro-5H-dibenzo[a,d]cyclohepten-5,10-imine maleate) was a gift from Dr. P. Anderson (Merck Sharp and Dohme, West Point, PA).

Quantitative analysis of antagonistic drug effects. In experiments in which the interactions of agonists and antagonists at the EAA receptor channel complex were examined, the mode of antagonism was evaluated according to the method described by Ascher et al. (1979) and Rang (1981). At equilibrium, the antagonistic effect of a drug is described by the response ratio $\Lambda$, defined as

$$
\Lambda=R(0) / R(B),
$$

where $R(0)$ is the fraction of receptors activated when no antagonist is present, and $R(B)$ is the fraction activated by the same agonist concentration in the presence of the antagonist. Thus, $\Lambda$ can be obtained experimentally from 2 measured responses. A convenient index for the degree of antagonism can be expressed by $\Lambda-1$, so that if $\Lambda-1=0$, there is no antagonism. On the basis of this scheme, a competitive mode of antagonism can be distinguished from the actions of uncompetitive channel blocking antagonists. With a competitive antagonist, the degree of block, which is expressed by $\Lambda-1$, is expected to decrease as the agonist concentration is increased, whereas with a channel blocking drug, $\Lambda-1$ increases with increasing agonist concentrations. 


\section{Results}

Whole-cell voltage-clamp recordings were usually made 6-24 hr after dissociation of the retinas. No apparent variations of the ganglion cell responses elicited by EAA analogs have been noticed at the different times (Aizenman et al., 1988). Recordings were made from a total of 108 solitary, randomly chosen ganglion cells of different sizes, identified by their blue labeling under epifluorescence. In these cultures, at least 2 subclasses of ganglion cells can be identified on the basis of size (Perry, 1979; Dräger and Hofbauer, 1984; Lipton and Tauck, 1987): large $\alpha$-like cells and smaller types. However, no differences in EAA responses based upon these subclasses were noted. The cells were typically spherical in shape, did not exceed $25 \mu \mathrm{m}$ in diameter, and lacked long processes because of the short incubation time. Therefore, an adequate space-clamp in the wholecell recording mode was ensured.

\section{NMDA and kainate currents}

Thirty-eight out of 55 cells tested (69\%) showed responses following microperfusion of the glutamate analog NMDA at a concentration of $200 \mu \mathrm{M}$, the maximal nondesensitizing dose (Aizenman et al., 1988). In the absence of extracellular $\mathrm{Mg}^{2+}$ and with the cells voltage-clamped to their resting potential of $-60 \mathrm{mV}$ (Lipton and Tauck, 1987), the maximal currents evoked by NMDA, when present, were usually small, varying from -5 to $-40 \mathrm{pA}$. Under the same conditions, kainate $(125 \mu \mathrm{M})$ caused inward currents in all retinal ganglion cells to which it was applied ( $n=67)$. Kainate-induced currents were nondesensitizing at this concentration and ranged in amplitude from -80 to $-750 \mathrm{pA}$. In the solutions used here, the responses induced by both kainate and NMDA reversed in polarity near $0 \mathrm{mV}$. In general, when both glutamate analogs were applied separately to the same cell, the kainate response usually exceeded the NMDA response by 1 or 2 orders of magnitude at a given concentration (Fig. 1 1 ). In rare cases, however, the ratio of the currents generated by kainate and NMDA came close to 1 (Fig. $1 B$ ). The scattergram in Figure $1 C$ shows that, for 2 different concentrations of NMDA and kainate, there is a poor correlation between the amplitudes of currents generated by these agonists (Spear-

Figure 1. Currents induced by $N$-methyl-D-aspartate (NMDA) and kainate in the whole-cell configuration recorded from solitary retinal ganglion cells in culture. Traces show the variation of current responses evoked by $200 \mu \mathrm{M}$ NMDA and $125 \mu \mathrm{M}$ kainate for different cells. Drugs were applied by pressure ejection from glass microcapillaries during the time period indicated by the dashed line above the traces. The neurons were voltage-clamped at $-60 \mathrm{mV}$, at which potential both EAA analogs induced inward currents indicated as downward deflections. $A$, Relation between current amplitudes observed for the majority of the cells tested. In this case, $200 \mu \mathrm{M}$ NMDA induced an inward current of $-10 \mathrm{pA}$, and $125 \mu \mathrm{M}$ kainate produced a response of $-738 \mathrm{pA}$, which was at the upper end of the scale for kainate responses observed. $B$, Rarely, NMDA and kainate at these concentrations induced currents of similar amplitude in a given cell. NMDA elicited an unusually large inward current of $-47 \mathrm{pA}$, while kainate produced a current with an amplitude of -97 pA. $C$, Scattergram shows the amplitudes of kainate-induced currents (abscissa) versus the NMDA-induced currents (ordinate) for various ganglion cells $(n=22)$. Current amplitudes generated by $50 \mu \mathrm{M}$ NMDA versus $50 \mu \mathrm{M}$ kainate and by $200 \mu \mathrm{M}$ NMDA versus $125 \mu \mathrm{M}$ kainate, were plotted. Because of the lack of NMDA responses in a fraction of cells, some points in the diagram cluster at the abscissa. Otherwise a poor correlation is seen between the currents induced by kainate and NMDA (see text).
A

$200 \mu M N M D A$

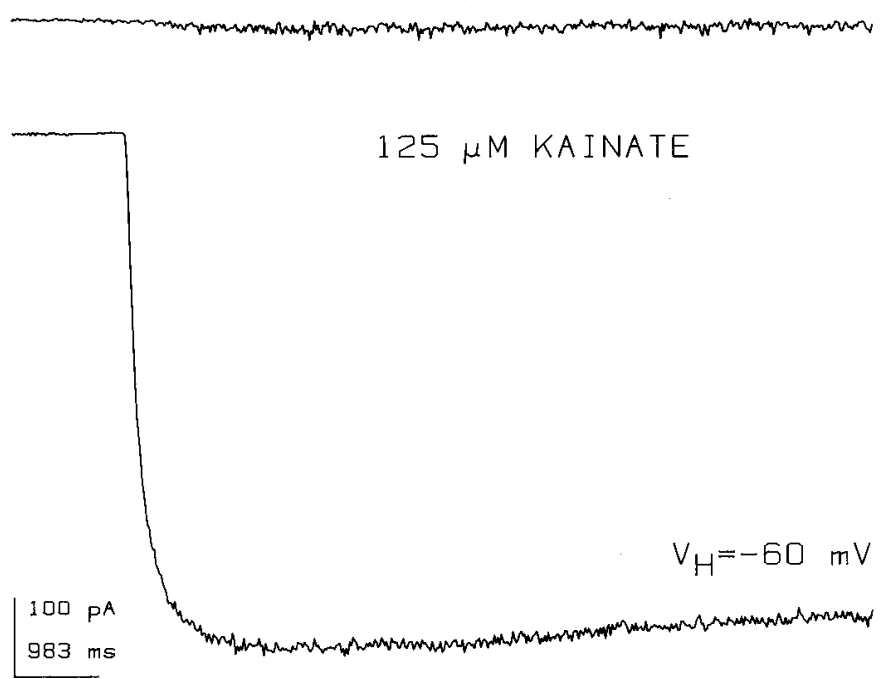

B

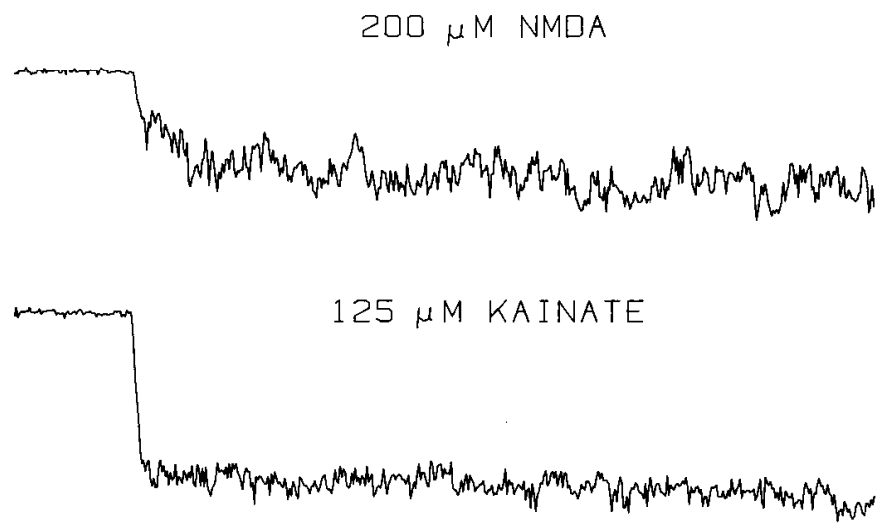

$40 \mathrm{PA}^{\mathrm{A}}$

$983 \mathrm{~ms}$

$V_{H}=-60 \mathrm{mV}$

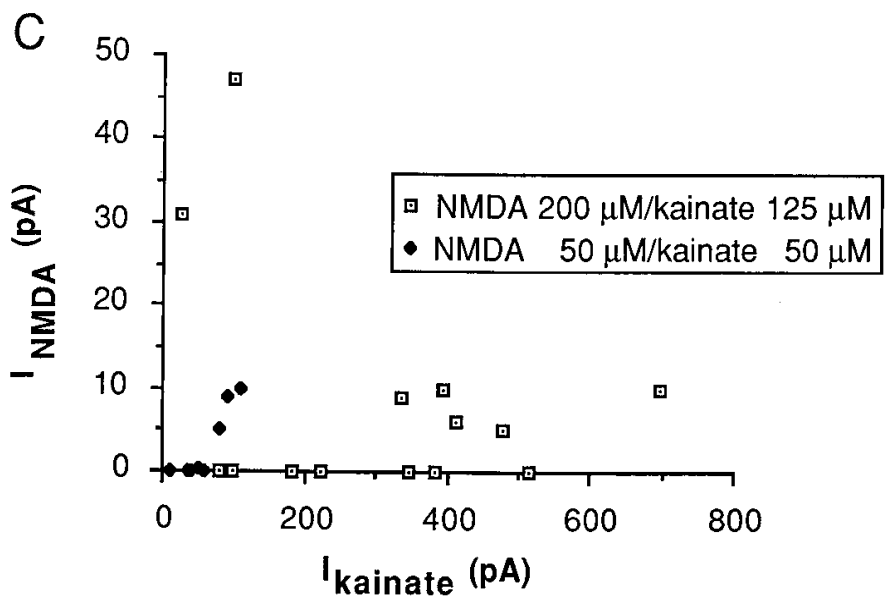



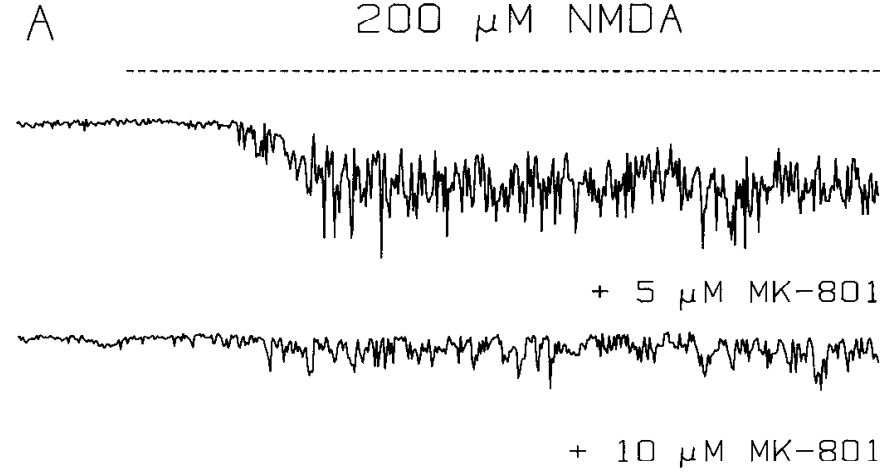

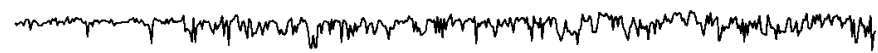

$+20 \mu M M K-801$

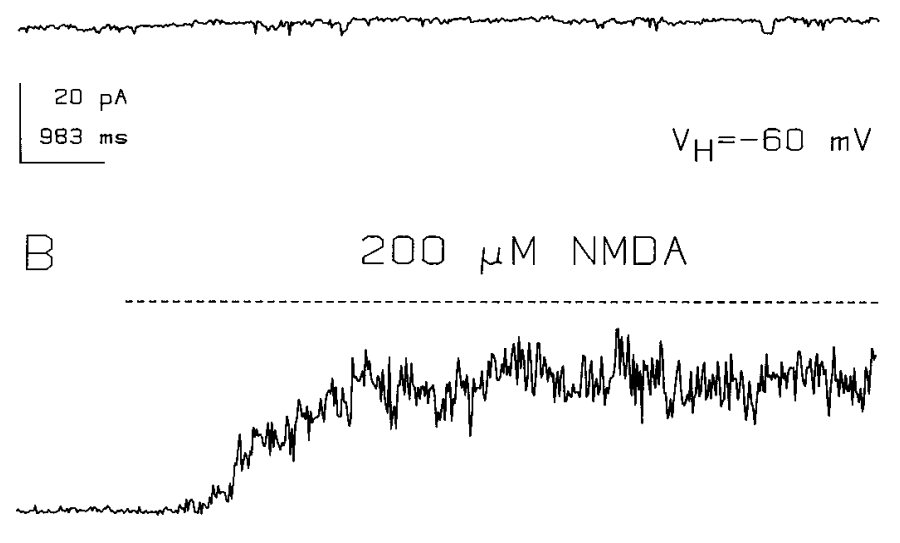

$+5 \mu M M K-801$

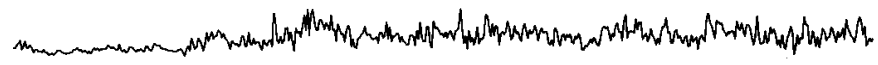

$+10 \mu M M K-801$

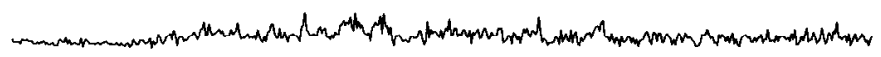

$+20 \mu \mathrm{MMK}-801$

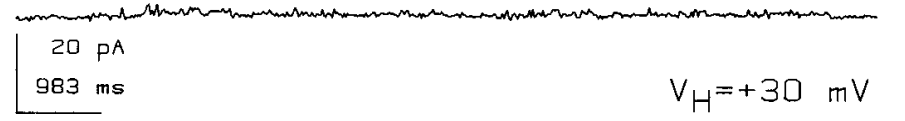

C

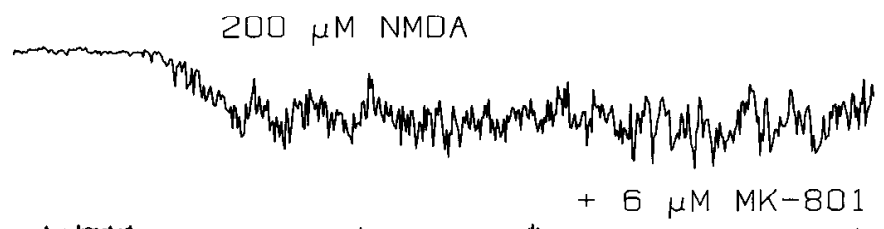

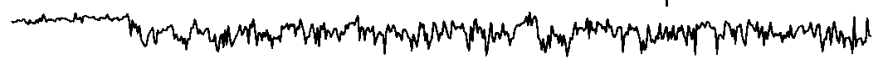

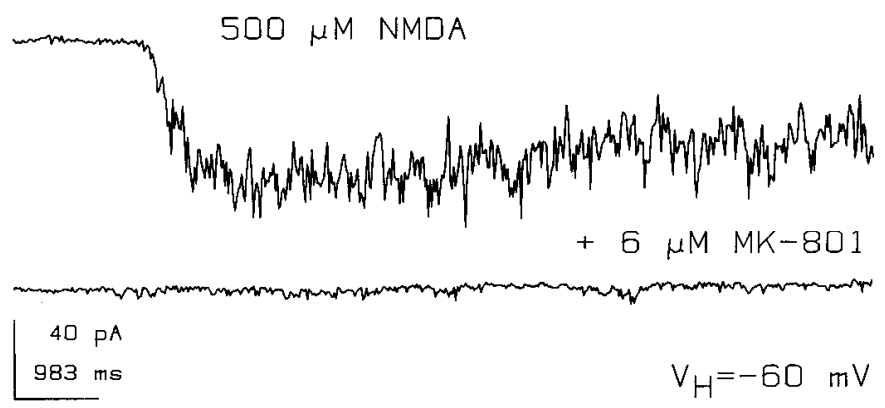

Figure 2. Effects of the antagonist MK-801 on the currents induced by NMDA. Responses were recorded from a retinal ganglion cell after addition of $200 \mu \mathrm{M}$ NMDA and simultaneously applied antagonist (at concentrations of 5,10 , or $20 \mu \mathrm{M}$ ). Recordings in $A$ and $B$ were made from the same cell, voltage-clamped at its resting potential of $-60 \mathrm{mV}(A)$ and $+30 \mathrm{mV}(B)$. The traces show the voltage-independent antagonistic effect of MK801 on NMDA currents under these conditions; $20 \mu \mathrm{M}$ MK-801 was the minimal concentration of the drug to totally block the NMDA-induced responses. $C, D$. The antagonistic effect of MK-801 $(6 \mu \mathrm{M})$ on NMDA-induced currents for 2 different agonist concentrations. The neuron was voltage-clamped at both $-60 \mathrm{mV}(C)$ and $+30 \mathrm{mV}(D)$. This concentration of MK-801, which partially antagonized the current responses to 200 $\mu \mathrm{M}$ NMDA, was found to almost totally block the responses induced by $500 \mu \mathrm{M}$ NMDA at both potentials. This indicates that the degree of block by MK-801 increases with increasing agonist concentration. The apparent nonlinearity of the control responses in $A$ and $B$ is likely due to residual magnesium in the bathing medium.

man rank correlation coefficient, $R_{\mathrm{s}}=0.197 ; p=0.381 ; n=$ 22). No relationship between the size of the ganglion cells and their responses to either EAA was found.

\section{Effects of $M K-801$ and $P C P$}

To gain insight into the configuration of the NMDA and kainate receptor binding sites and their association with an ionophore, we studied the effects of the anticonvulsant MK- 801 and the dissociative anesthetic $\mathrm{PCP}$ on the ganglion cell responses to NMDA and kainate.

Influence on NMDA currents. MK-801 was found to antagonize the NMDA $(200 \mu \mathrm{M})$-elicited inward currents $\left(V_{\mathrm{H}}=-60\right.$ $\mathrm{mV} ; n=9$ ). The minimal concentration for total blockade of NMDA currents by this antagonist was $20 \mu \mathrm{M}$, at which dose infrequent single-channel openings could be observed in the whole-cell recording mode (Fig. $2 A$ ). MK-801 produced the 


\section{A} $200 \mu M$ NMDA

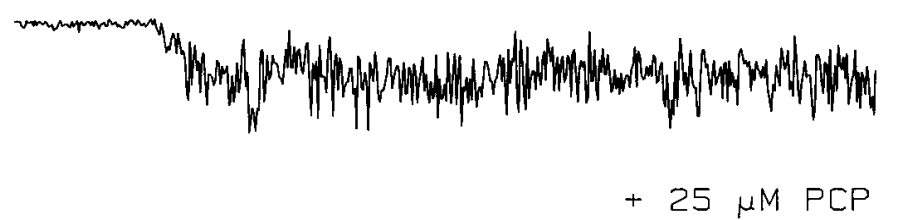

$+50 \mu M$ PCF

$+75 \mu M$ PCP
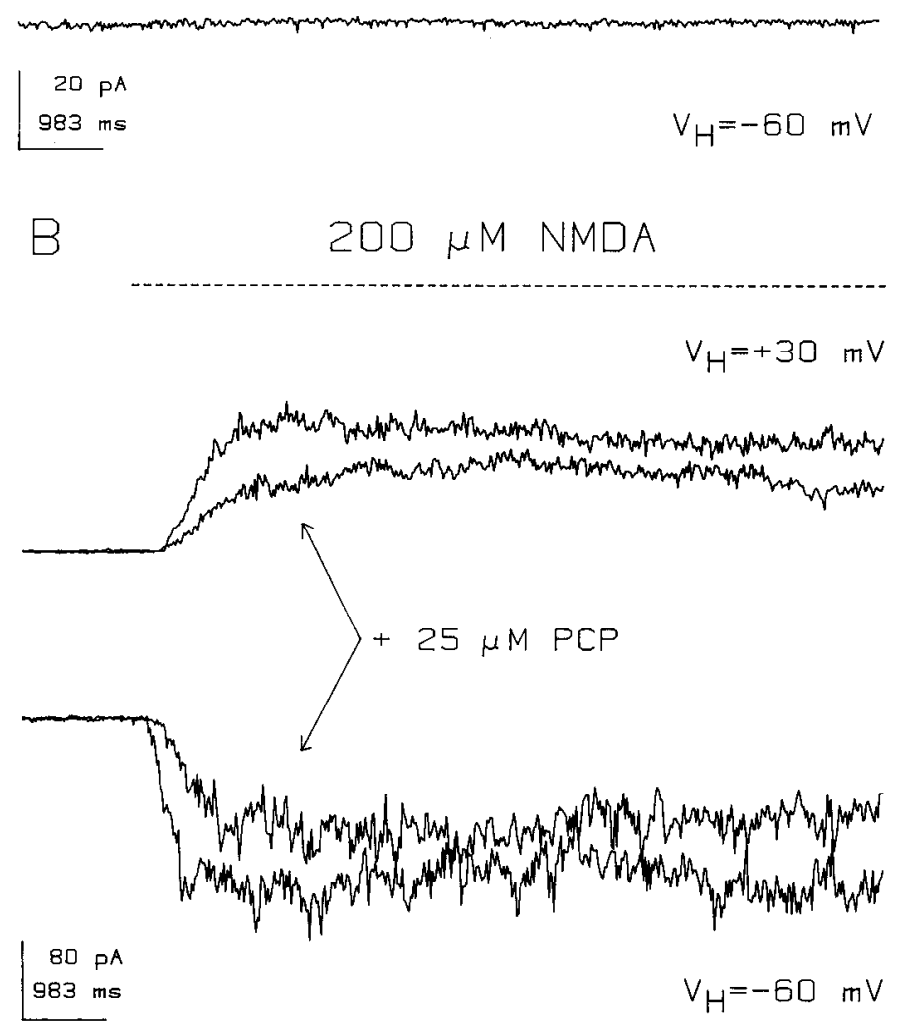

same degree of block regardless of the membrane holding potential (Fig. 2B).

It has been suggested that the MK-801 antagonism of NMDA is noncompetitive and agonist-dependent in character (Kemp et al., 1986; Wong et al., 1986). In our preparation, a concentration of $6 \mu \mathrm{M}$ MK- 801 , which only partially antagonized the response to $200 \mu \mathrm{M}$ NMDA at the resting potential, almost totally blocked the response to $500 \mu \mathrm{M}$ NMDA (Fig. $2 C$ ). The same pattern of inhibition was observed at membrane potentials of $+30 \mathrm{mV}$ (Fig. 2D). A similar effect was seen in the action of PCP on NMDA responses $(n=19)$. It was observed that $75 \mu \mathrm{M}$ PCP totally and reversibly abolished NMDA $(200 \mu \mathrm{M})$-induced currents (Fig. $3 A$ ) at $60 \mathrm{mV}$. The depression of NMDA responses was also found to be voltage-independent (Fig. $3 B$ ). In addition, for the cell illustrated in Figure $3 C$ the degree of block produced by $25 \mu \mathrm{M}$ PCP, a dose that half-maximally suppressed
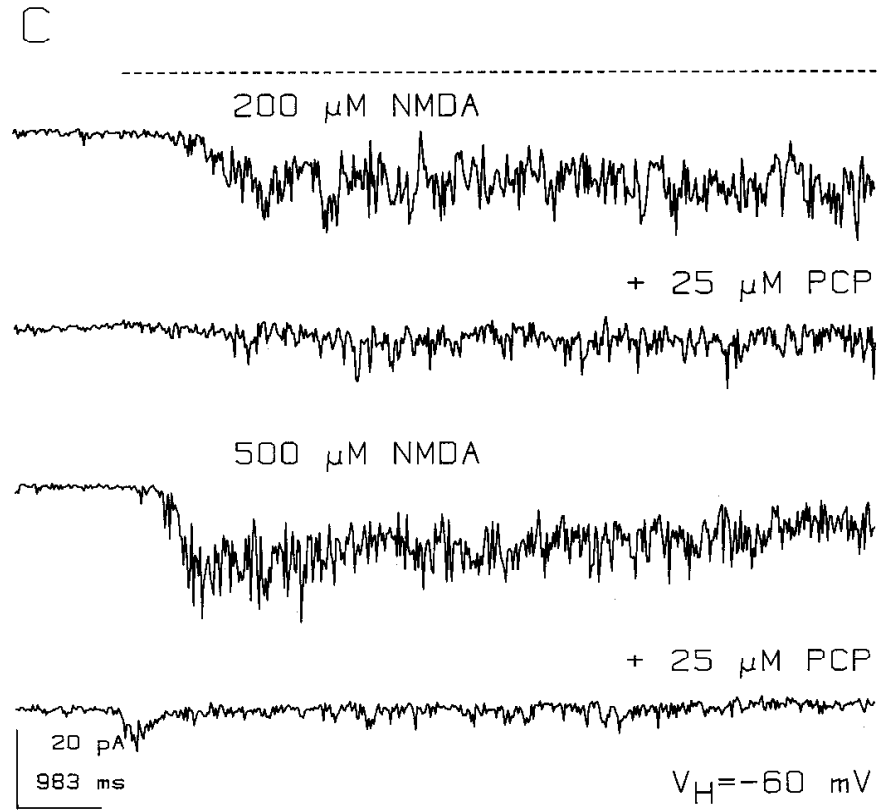

Figure 3. Effects of the antagonist phencyclidine (PCP) on the currents induced by NMDA. $A$, Effects of 3 different concentrations of PCP (25, 50 , and $75 \mu \mathrm{M})$ are shown with the neuron voltage-clamped at $-60 \mathrm{mV}$. Although the block of NMDA currents was complete when $75 \mu \mathrm{M} \mathrm{PCP}$ was applied, most of the NMDA-induced inward current was suppressed by $25 \mu \mathrm{M}$ PCP in this ganglion cell. $B$, Rccords from another cell show that PCP $(25 \mu \mathrm{M})$ blocked the currents induced by NMDA $(200 \mu \mathrm{M})$ to the same degree irrespective of the cell's holding potential. At both $V_{\mathrm{H}}$ $=+30 \mathrm{mV}$ (top traces) and $V_{\mathrm{H}}=-60 \mathrm{mV}$ (bottom traces), the NMDAevoked current was depressed by approximately $30 \%$. C, PCP $(25 \mu \mathrm{M})$ partially antagonized the current responses induced by $200 \mu \mathrm{M}$ NMDA in this neuron. However, the same dose of antagonist suppressed the cell's response to $500 \mu \mathrm{M}$ NMDA to a greater degree.

the $200 \mu \mathrm{M}$ NMDA response, increased with higher concentrations of agonist. The diagram in Figure 4 shows the parameter $\Lambda-1$ (defined in Materials and Methods), which expresses the degree of blockade by both MK-801 and PCP as a function of the concentration of NMDA. As may be noted, the degree of inhibition by both antagonists increases with increasing NMDA concentration. Rang (1981) showed that this type of $\Lambda-1$ versus agonist curve suggests that both MK-801 and PCP may act as uncompetitive blockers of the open state of the NMDA receptor-ionophore.

Effects of $M K-801$ and PCP on kainate-induced currents. Kainate (75-150 $\mu \mathrm{M})$-induced responses were found to be largely unaffected by either PCP ( $100 \mu \mathrm{M} ; n=9$; Fig. $5 A$ ) or MK-801 $(20 \mu \mathrm{M} ; n=8$; Fig. $5 B$ ). These 2 antagonists produced no response when applied in the absence of the glutamate analogs (Fig. 5C). 


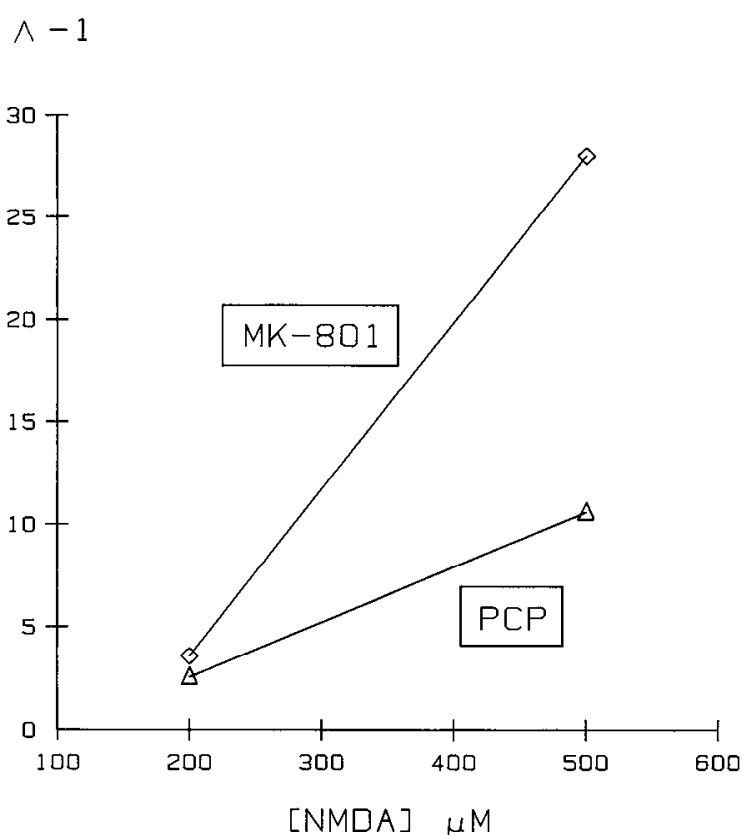

Figure 4. The parameter $\Lambda-1$ (defined in Materials and Methods) as a function of the NMDA concentration for the antagonistic effects of both MK-801 $(6 \mu \mathrm{M})$ and PCP $(25 \mu \mathrm{M})$. The degree of block by either one of the NMDA antagonists (expressed as $\Lambda-1$ ) increased as the agonist concentration ([NMDA]) increased.

\section{NMDA-kainate interaction}

Figure $6 A$ shows responses of a retinal ganglion cell after addition of 50 and $125 \mu \mathrm{M}$ kainate, both in the absence and presence of $200 \mu \mathrm{M}$ NMDA. The coapplication of NMDA and kainate produced a smaller response than that elicited by kainate alone. The same data are represented in Figure $6 B$ by plotting the parameter $\Lambda-1$ as a function of kainate concentration. The negative slope of the resulting graph is indicative of a competitive block (Rang, 1981) of kainate-induced currents by NMDA. Alternatively, if kainate receptors show positive cooperativity (see Migani et al., 1985), NMDA may act as a noncompetitive antagonist acting at an allosteric site on the kainate receptor molecule. To confirm that this antagonism actually represents an action of NMDA at the kainate receptor, we tested this block in cells having no measurable response to NMDA alone. Figure $6 C$ denotes such an experiment, in which NMDA $(200 \mu \mathrm{M})$ was still observed to substantially reduce the current generated by kainate $(125 \mu \mathrm{M})$. Measured for a total of 11 cells, the responses produced by $125 \mu \mathrm{M}$ kainate were decreased by an average value of $51 \%$ by $200 \mu \mathrm{M}$ NMDA. This value includes those cells with no underlying NMDA responses and takes into account the currents elicited by NMDA in those cells in which one could be measured.

\section{Effects of PCP and $M K-801$ on the NMDA-kainate interaction}

PCP and MK-801 were shown to be putative blockers of the open NMDA channel. If NMDA and kainate activate a common channel by binding to their specific receptors, the blockade of the NMDA-ionophore by either antagonist should prevent the induction of current flow by simultaneously applied kainate. Figure $7 A$ illustrates the addition of $125 \mu \mathrm{M}$ kainate, in conjunction with $200 \mu \mathrm{M}$ NMDA and $100 \mu \mathrm{M}$ PCP. This dose of
NMDA plus PCP resulted in no net current (middle trace). The combination of all 3 drugs produced an increase in membrane conductance of the same order of magnitude as that produced by kainate alone in other cells. The net current was similar to that produced by NMDA and kainate applied together (Fig. 7B). The same phenomenon was observed after substituting MK$801(10-20 \mu \mathrm{M})$ for PCP (not shown).

In another set of experiments we tested whether or not the NMDA and kainate sites were linked by examining the agonistinduced currents in the presence and absence of the antagonist PCP or MK-801. We define the parameters $\alpha$ and $\alpha^{\prime}$ as follows:

$$
\begin{aligned}
& \text { (1) } \alpha^{\prime}=\left(I_{\mathrm{KA}}-I_{\mathrm{A}}\right) / I_{\mathrm{K}} \\
& \text { (2) } \alpha^{\prime}=\left(I_{\mathrm{KNA}}-I_{\mathrm{NA}}\right) / I_{\mathrm{KN}},
\end{aligned}
$$

where $I_{\mathrm{K}}, I_{\mathrm{A}}$, and $I_{\mathrm{KA}}$ are, respectively, the amplitudes of the currents produced by kainate, antagonist (PCP or MK-801), and both kainate and antagonist together, and $I_{\mathrm{KN}}, I_{\mathrm{KNA}}$, and $I_{\mathrm{NA}}$ are, respectively, the amplitudes of the currents resulting after the addition of kainate and NMDA together, of kainate, NMDA, and antagonist together, and of NMDA and antagonist together. The contribution of the NMDA-induced current to $I_{\mathrm{KN}}$ was generally small (see Fig. 1). These equations represent the effects of either PCP or MK-801 on the kainate-induced current, both in the absence and presence of NMDA. Equation (1) implies that if there is no effect of the NMDA antagonists on the kainate response, $\alpha$ would be expected to be close to 1 , independent of the kainate concentration. If the lack of effect of the antagonist on the current response induced by binding to the kainate receptor is not altered when NMDA is added, then $\alpha^{\prime}$ in equation (2) would also approach unity. For convenience, we used concentrations of $100 \mu \mathrm{M} \mathrm{PCP}$ and $20 \mu \mathrm{M}$ MK-801, which were shown to totally abolish the responses to $200 \mu \mathrm{M}$ NMDA (Figs. $2,3)$. This reduced the term $I_{\mathrm{NA}}$ to zero and simplified equation (2). Since both antagonists produced no responses when added alone at these concentrations (Fig. $5 \mathrm{C}$ ), the term $I_{\mathrm{A}}$ was also zero. In this manner, either $\alpha$ or $\alpha^{\prime}$ could be obtained experimentally in one cell, for 2 different concentrations of kainate, with only 4 pressure-ejection pipettes. For the number of cells tested in this manner $(n=11)$, it is statistically irrefutable that at least some cells were included that had measurable NMDA responses in the absence of antagonists.

Two experiments in which both $\alpha$ and $\alpha^{\prime}$ were obtained for 2 kainate concentrations are shown in Figure 8 . Figure $8 A$ presents the currents elicited by 50 and $125 \mu \mathrm{M}$ kainate both in the

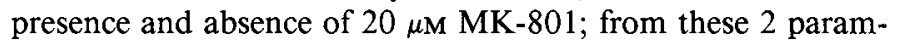
eters, $\alpha$ can be calculated. Figure $8 B$ shows the currents obtained in an experiment with $100 \mu \mathrm{M}$ PCP, from which $\alpha^{\prime}$ can be calculated for 2 concentrations of kainate ( 50 and $125 \mu \mathrm{M}$, in the presence of $200 \mu \mathrm{M}$ NMDA). Figure $9, A, B$, summarizes the values of $\alpha$ and $\alpha^{\prime}$ obtained for 2 kainate concentrations for both PCP and MK-801. For each antagonist, $\alpha$ and $\alpha^{\prime}$ were found not to be statistically different.

If $\alpha$ and $\alpha^{\prime}$ had been found to be substantially different, then the NMDA and kainate responses would have to have been linked, perhaps by a common ionophore. The results show that the antagonists had no effect on the kainate response in the absence of NMDA [eq. (1)]; also, there was no significant effect of the antagonists on the response mediated by kainate receptor activation when NMDA was added, since the values of $\alpha$ and $\alpha^{\prime}$ are comparable. Therefore, the fact that the antagonists are thought to be open channel blockers suggests that the location of action of PCP and MK-801 on the NMDA-activated channels 
A
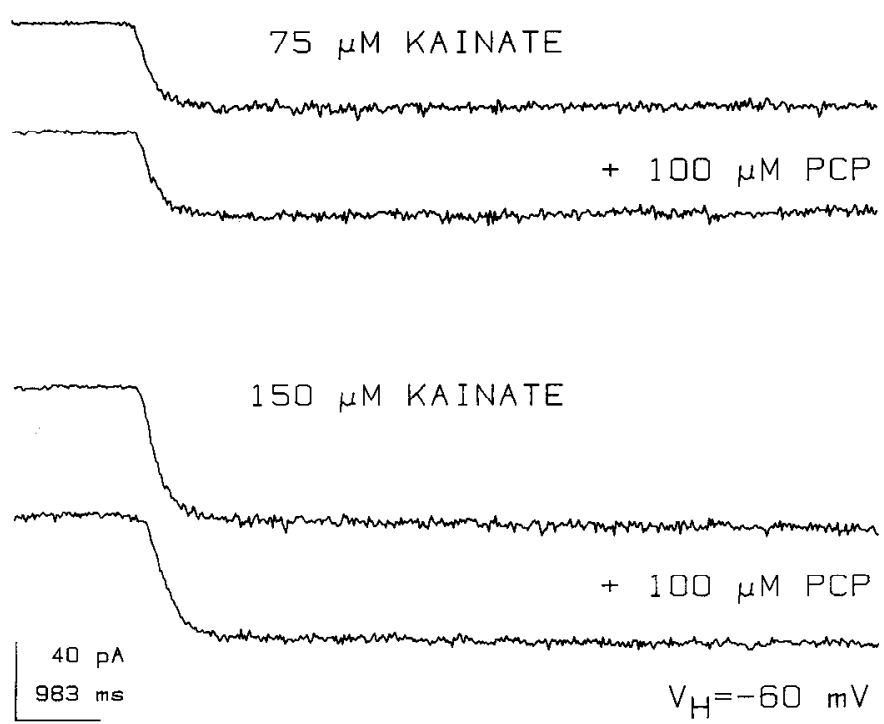

$125 \mu M$ KAINATE
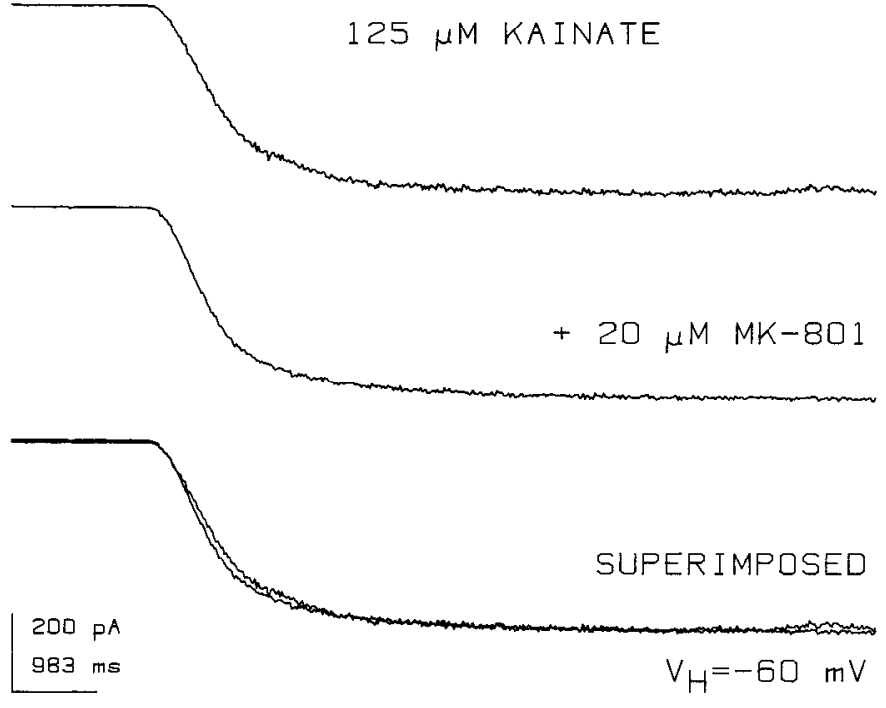

is different from the channels activated by kainate (or kainate in the presence of NMDA as a competitive or allosteric inhibitor).

In addition, the value of $\alpha^{\prime}$ at different concentrations of kainate may also prove useful in determining whether or not kainate and NMDA share a common ionophore, as explained below. When kainate, NMDA, and the antagonist PCP or MK-801 were added together, a large current resulted. Under the conditions of the experiment, the large current induced by binding to the kainate receptor could have been due to 2 different mechanisms: (1) activation of a separate conductance that is independent of PCP or MK-801 blockade of the NMDA-activated channels, or (2) removal of the block by PCP or MK-801 by some unknown mechanism, such as displacement of the antagonist by kainate and activation of the associated ionophore (which might be shared by both kainate and NMDA). If the
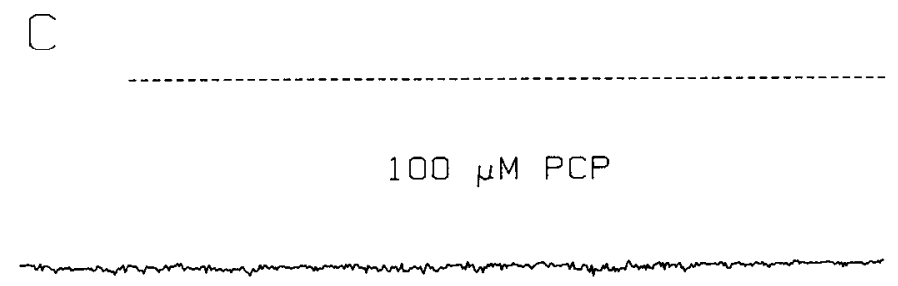

$20 \mu M \quad M K-801$

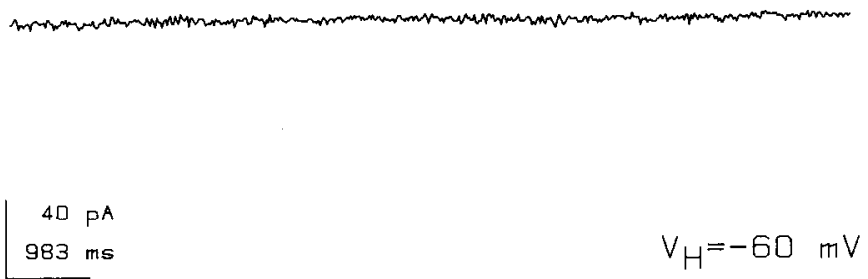

Figure 5. Whole-cell responses of retinal ganglion cells to kainate and the influence of simultaneously applied PCP $(A)$ and MK-801 $(B)$. Concentrations of PCP $(100 \mu \mathrm{M}$ in $A)$ and MK-801 $(20 \mu \mathrm{M}$ in $B)$, which were shown to totally block the current responses to $200 \mu \mathrm{M}$ NMDA, did not affect the inward currents cvoked by different concentrations of kainate $(75-150 \mu \mathrm{M})$. The neurons were voltage-clamped at a holding potential of $-60 \mathrm{mV}$. $C$, Control showing that the application of 100 $\mu \mathrm{M}$ PCP or $20 \mu \mathrm{M}$ MK-801, respectively, did not produce responses in retinal ganglion cells.

latter were correct, then $\alpha^{\prime}$ would have been significantly accentuated by increasing concentrations of kainate, but this was not observed experimentally (Fig. 9).

\section{Discussion}

The objective of the present investigation was to evaluate the responses of the glutamate analogs kainate and NMDA on mammalian retinal ganglion cells, the interactions between these 2 agonists, and how this interaction might be affected by the NMDA antagonists MK-801 and PCP. These experiments also yielded insight into the question of whether kainate and NMDA activate the same or separate ion channels. Referring to these aims, 3 major conclusions can be drawn from our observations.

First, the amplitudes of the currents produced by nearly maximal nondesensitizing doses of NMDA and kainate seem to be independent and not correlated with each other for the popu- 

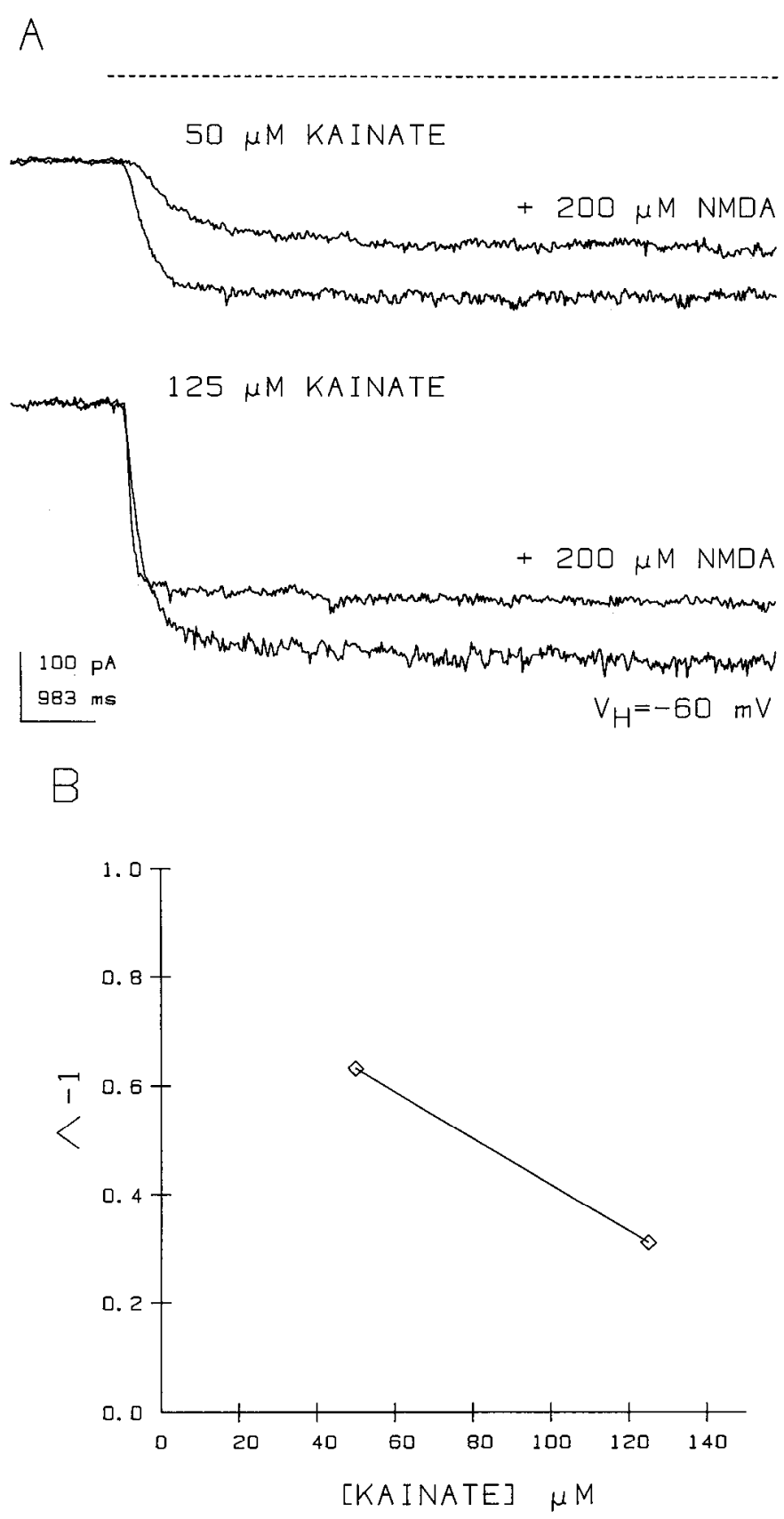

lation of ganglion cells tested. Not only did the ratio of the currents produced by both agonists vary substantially, but as many as $31 \%$ of the cells had no measurable response to NMDA, while all cells responded to kainate. Second, NMDA appears to act as either a competitive or allosteric antagonist at the kainate receptor. Third, the noncompetitive antagonist action of $\mathrm{MK}$ 801 and PCP on the NMDA receptor channel does not influence a simultaneously evoked kainate response, suggesting a segregation of separate receptor-ionophore complexes for each EAA analog.

The ability of the novel NMDA antagonist MK-801 (Clineschmidt et al., 1982) to antagonize NMDA responses has previously been shown in electrophysiological and biochemical experiments to be use-dependent and noncompetitive. Thus, the degree of blockade augments with increasing NMDA concentration (Kemp et al., 1986; Wong et al., 1986). Using ${ }^{3} \mathrm{H}-\mathrm{MK}$ -
C

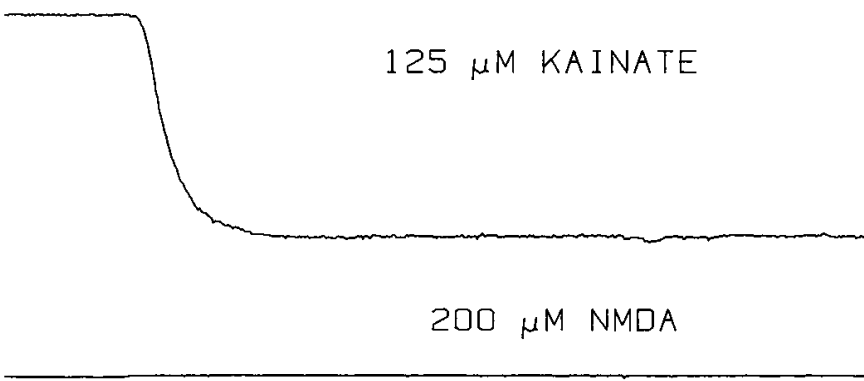

$125 \mu M$ KAINATE + 200 $\mathrm{M}$ NMDA

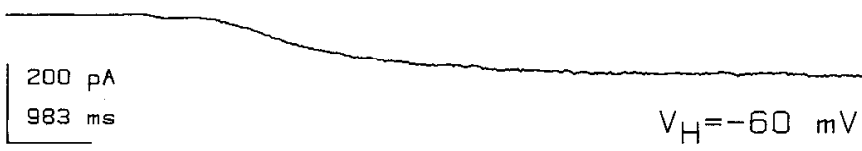

Figure 6. Whole-cell current recordings showing the interaction of NMDA and kainate in retinal ganglion cells. $A$, The coapplication of kainate and NMDA produced a smaller response than that elicited by kainate alone, as shown for 2 different concentrations of kainate (50 and $125 \mu \mathrm{M})$. The values for this experiment are demonstrated again in the diagram in $B$, where the degree of block by NMDA $(\Lambda-1)$ is plotted as a function of the kainate concentration. The negative slope of the graph, showing a decrease in the degree of block with increasing agonist concentration, is consistent with a competitive or allosteric mode of antagonism for the action of NMDA on kainate responses. $C, \mathrm{~A}$ concentration of $200 \mu \mathrm{M}$ NMDA, which did not produce a response itself in this ganglion cell (middle trace), still resulted in a decrease in the inward current elicited by $125 \mu \mathrm{M}$ kainate (top trace) by $66 \%$ (bottom trace). This suggests that NMDA is acting as an antagonist at the kainate binding site.

801, a unique class of high-affinity binding sites could be demonstrated in rat brain membranes (Wong et al., 1986), and other NMDA antagonists, such as PCP, ketamine, or SKF 10.047 were shown to compete for the same binding sites. Lowering the agonist concentration, as well as application of competitive NMDA antagonists, such as AP5 or AP7, reduced the number of binding sites but not the affinity of ${ }^{3} \mathrm{H}-\mathrm{MK}-801$ (Foster and Wong, 1987). These observations suggested that MK-801 binds to the open state of the NMDA-activated ion channel (Foster and Wong, 1987). The same mode of noncompetitive antagonism, indicating a slow open channel block, has also been proposed for PCP and ketamine in cultured mouse spinal cord neurons (Honey et al., 1985).

The results presented here show that the degree of block produced by MK-801 and PCP increases as the NMDA concentration is raised, and thus support the aforementioned hypoth- 

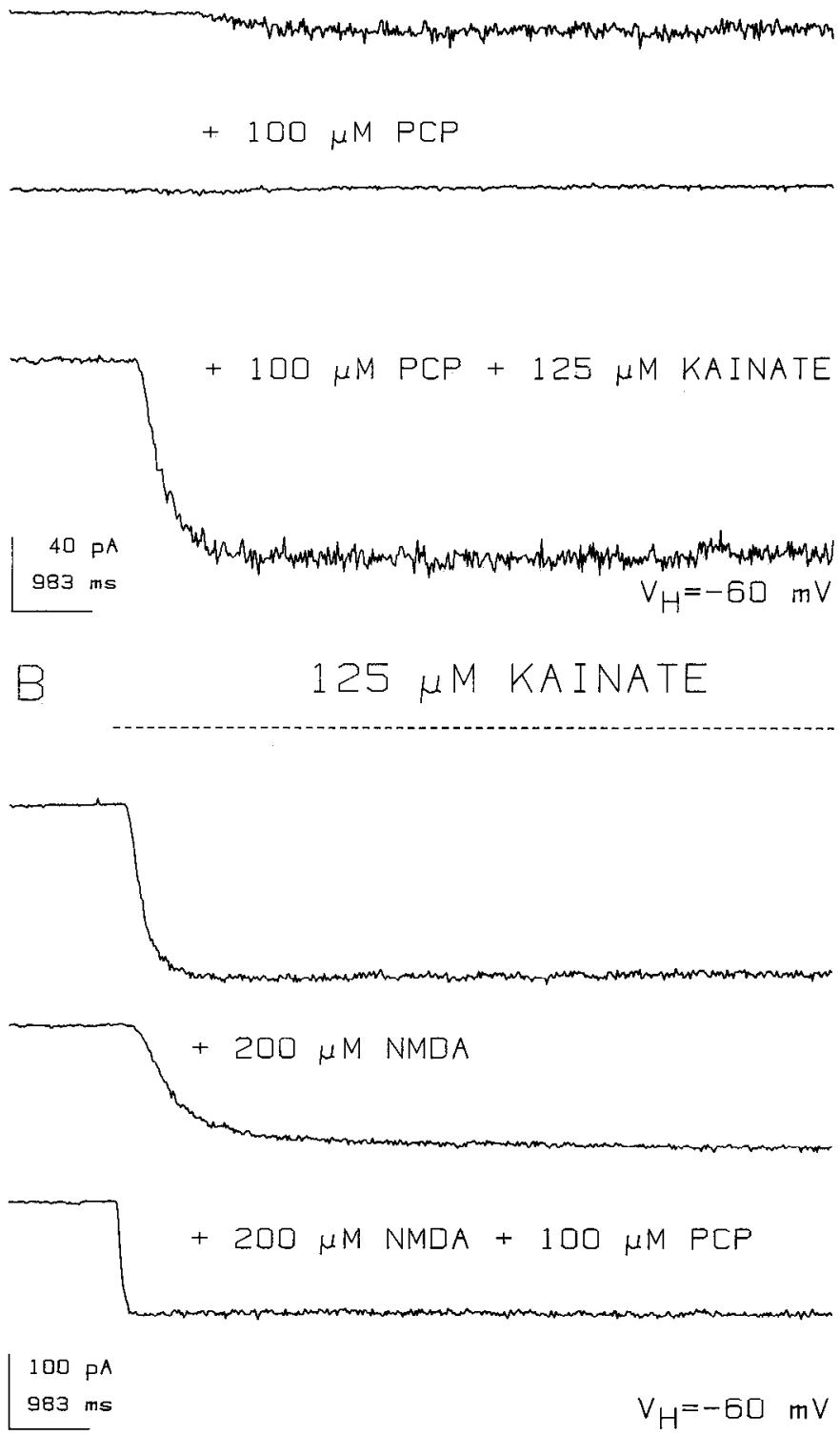

Figure 7. Effects of kainate on the PCP-MK-801-NMDA interaction in retinal ganglion cells. $A$, Whole-cell currents induced by $200 \mu \mathrm{M}$ NMDA were shown to be suppressed by simultaneous application of $100 \mu \mathrm{M}$ PCP. Addition of $125 \mu \mathrm{M}$ kainate to the composition of the drugs introduced a large macroscopic inward current (bottom trace), with the neuron voltage-clamped at $-60 \mathrm{mV}$. $B$. The magnitude of the inward current evoked by all 3 drugs is similar to that induced by simultaneous pressure ejection of both NMDA and kainate.

esis. This particular type of noncompetitive open channel blocking mechanism has been described in rat autonomic ganglia for cholinergic agents by Ascher et al. (1979), where the term "uncompetitive" was used. Other possible modes of uncompetitive action of an antagonist include a reduction in the single-channel conductance (or even prevention from upening altogether) and induction of a desensitized state. In future experiments, single-channel recordings will be necessary to confirm the possibility that PCP and MK-801 operate as true
A

$50 \mu M$ KAINATE

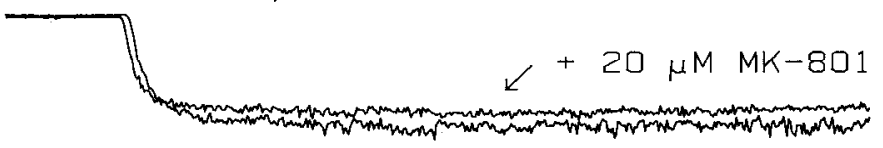

$125 \mu M$ KAINATE
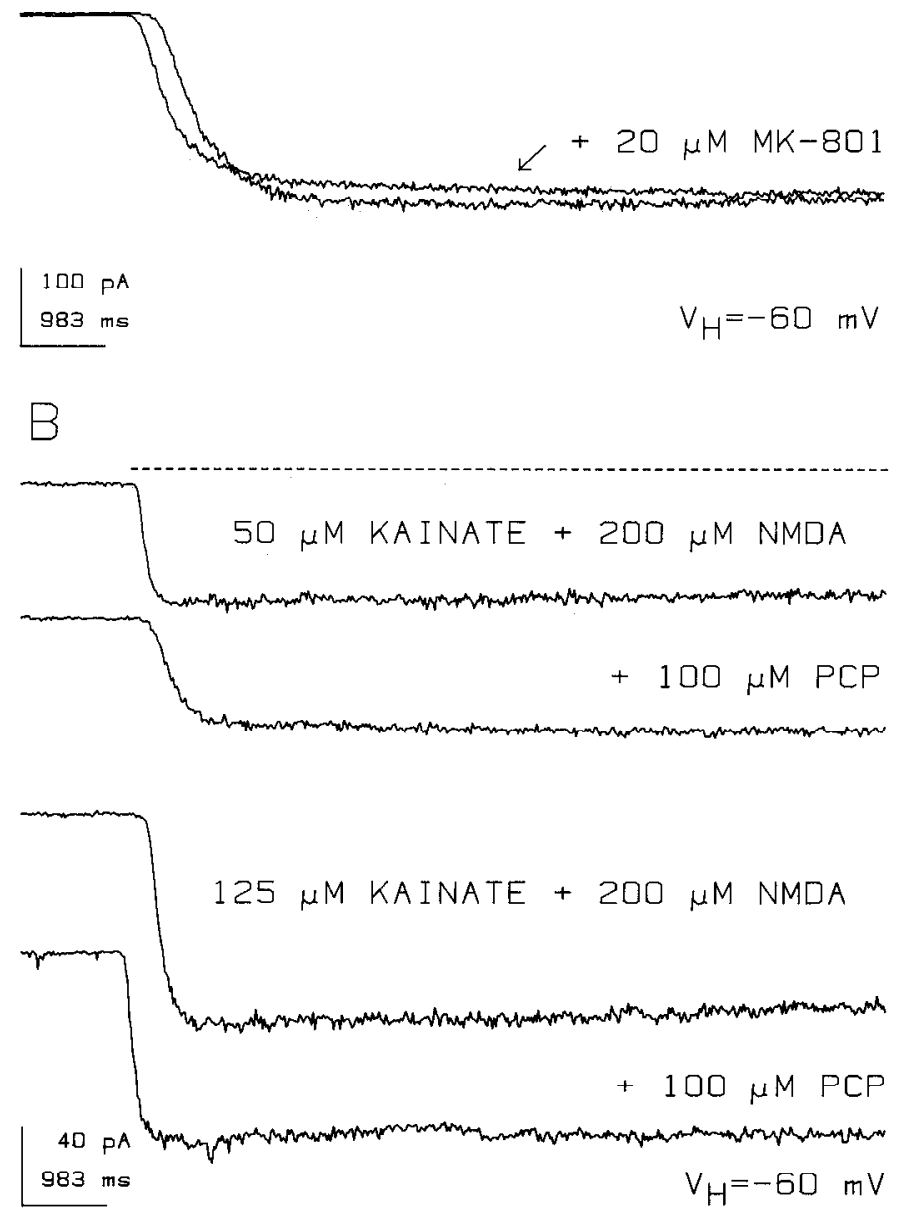

Figure 8. Whole-cell responses from retinal ganglion cells showing that kainate-evoked currents are independent of the NMDA antagonists MK801 and PCP in both the presence and absence of NMDA. $A$, A concentration of $20 \mu \mathrm{M}$ MK-801 is shown not to significantly affect the current responses evoked by 2 different concentrations of kainate ( 50 and $125 \mu \mathrm{M}) . B$, In the presence of $100 \mu \mathrm{M}$ PCP, the responses to 50 and $125 \mu \mathrm{M}$ kainate were again not substantially influenced by the addition of $200 \mu \mathrm{M}$ NMDA.

uncompetitive antagonists by means of a mechanism of slow open-channel blockade following agonist action.

A recent study by Honey et al. (1985) in cultured mouse spinal cord neurons reported that the inhibiting effect of PCP and ketamine on aspartate-induced responses was voltage-dependent. In direct contrast to the observations of these authors, we found that in the continued presence of agonist (NMDA), the degree of block produced by the antagonist (PCP or MK-801) was independent of the holding potential. Whether differences 
Figure 9. The type of results shown in Figure 8 are summarized diagrammatically for a total of 11 cells treated with the NMDA antagonists $\mathrm{PCP}(A)$ or MK$801(B)$. In both $A$ and $B, \alpha$ and $\alpha^{\prime}$ (as defined in the text), which express the effect of the NMDA antagonists on kainate-induced currents in the presence and absence of NMDA, are plotted as a function of the kainate concentration. Values shown are mean plus SEM. For each antagonist, $\alpha$ and $\alpha^{\prime}$ were not statistically different at either concentration ( $t$ test), nor did $\alpha$ or $\alpha^{\prime}$ vary statistically between concentrations (paired $t$ test).
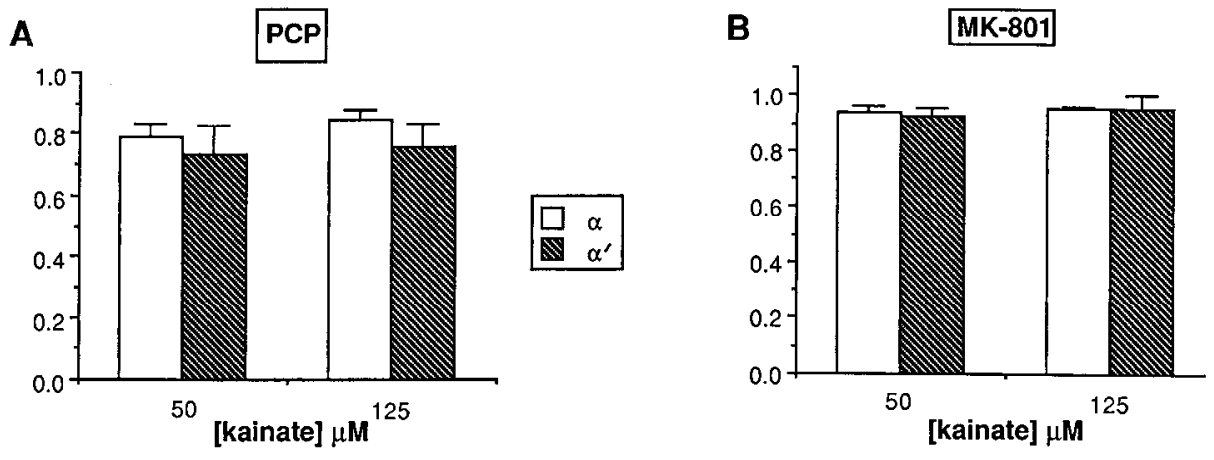

will also be seen in other preparations remains to be seen. This observed lack of voltage-dependence may be indicative of binding site segregation in the NMDA channel for $\mathrm{Mg}^{2+}$ cations and the 2 NMDA antagonists studied here, since the block effected by $\mathrm{Mg}^{2+}$ is highly voltage-dependent in rat retinal ganglion cells (Aizenman et al., 1988). In other types of neurons, it has been proposed that magnesium and other divalent cations perform their strong voltage-dependent block of NMDA-activated conductances by binding to the open state of the channel close to the intracellular surface at a point that is most sensitive to the transmembrane electrical field (Ascher and Nowak, 1987).

Several interesting interactions between the different EAA analogs at their receptor binding sites have already been reported. Quisqualate, besides binding to its specific receptor, has been shown to antagonize the kainate response (O'Dell and Christensen, 1986b; Aizenman et al., 1988), presumably via an uncompetitive mechanism (Ishida and Neyton, 1985). A minor diminution of kainate-evoked currents by simultaneously applied NMDA has recently been reported in chick spinal cord neurons in culture (Vlachovà et al., 1987). A similar interference, but with a higher potency for NMDA as an antagonist, was shown in our studies. Thus, NMDA seems to act at 2 distinct sites in cultured rat retinal ganglion cells: one is the NMDA recognition site, which is present in only $69 \%$ of the cells, and where NMDA opens its specific conductance; the other site is on the kainate-specific receptor of all cells, where it either competes with the agonist for the binding site or acts allosterically to reduce kainate-induced currents. In principle, a kainate antagonism at the NMDA receptor site is also plausible. However, the responses generated by the maximal nondesensitizing dose of NMDA $(200 \mu \mathrm{M})$ in our preparation were rather small, sometimes appearing only as an increase in noise during whole-cell recording. Thus, the direct effects of simultaneously applied kainate on the NMDA responses would likely go undetected. Furthermore, since every ganglion cell responds to the application of kainate, the lack of specific noncompetitive antagonists of the kainate-induced conductance prevents the analysis of possible kainate antagonism on NMDA-induced currents.

The crucial experiment (as shown in Fig. 7) for a better understanding of the EAA receptor-channel complex expressed in our preparation was the simultaneous pressure ejection of a composition of NMDA, kainate, and one of the NMDA antagonists (MK-801 or PCP). The current resulting from this mixture of drugs was entirely accounted for by the kainate response and was easily identified by its uniquely large amplitude. The kainate response was antagonized to some degree by NMDA, but this interaction was shown to be independent of the block produced by PCP or MK-801 of the NMDA-induced current. On the basis of our findings, the model of a single ionophore shared by each EAA receptor proposed by Jahr and Stevens (1987) and CullCandy and Usowicz (1987) seems to be questionable, at least in our preparation. If the ion channel is opened by NMDA and subsequently plugged by one of the putative NMDA channel blockers, no current flow through the shared channel should have been observed following the binding of kainate to its recognition site.

As demonstrated by single-channel recordings in other preparations (Nowak et al., 1984; Cull-Candy and Usowicz, 1987; Jahr and Stevens, 1987), the mean NMDA-induced conductance is larger than the kainate-evoked conductance; NMDA tends to activate $40-50 \mathrm{pS}$ channels, while kainate predominantly opens smaller 5-10 pS channels, but there is some overlap of the 2 agonists in activating the larger and smaller conductances. Different conductance states are generally based on a different open radius of the channel pore (Hille, 1984), and are also reflected in this case by the fact that the largest NMDAactivated channel is not only permeable to monovalent cations, as are the kainate-activated channels, but also permits significant calcium influx (MacDermott et al., 1986). Whether MK-801 and PCP, as well as $\mathrm{MG}^{2+}$ ions, prevent the large NMDA-activated conductance directly by physically clogging the ionophore, or allosterically via a conformational change of the receptor channel protein to regulate channel permeability is still unclear. In either case, however, the model of a shared ionophore may not account for the small $\mathrm{K}^{\prime}$ and $\mathrm{Na}^{\prime}$ conductances opened by kainate after the channel has been affected by the antagonists.

If a single ionophore was coupled to all EAA binding sites, one would predict a close relationship between the amplitudes of the whole-cell currents induced by NMDA and kainate. This, however, was not observed in our experiments. In addition, the macroscopic currents $\left(I_{\text {total }}\right)$ recorded in the whole-cell configuration should reflect the single-channel currents $(i)$ and open probability $\left(p_{0}\right)$ of the number of ion channels $(N)$ opened by an agonist according to $I_{\text {total }}=N \cdot i \cdot p_{0}$. Considering the ratio of NMDA-induced versus kainate-induced currents in our preparation, the open-channel probability of the NMDA conductance (mean open time $>5 \mathrm{msec}$; major conductance, $50 \mathrm{pS}$; see Mayer, 1987) would be calculated to be approximately $10^{3}$ times smaller than that of the major kainate-activated channel (mean open time, $0.5 \mathrm{msec}$; conductance, $5 \mathrm{pS}$ ). Assuming that we do not have to account for completely different agonist re- 
ceptor affinities, functional receptor-channel complexes, each with binding sites for both NMDA and kainate (i.e., $N=$ constant) can hardly account for our results.

From dose-response measurements, we were able to estimate half-maximum effective doses $\left(\mathrm{ED}_{50}\right)$ for kainate and NMDA to be less than $10^{-4} \mathrm{M}$, which were similar to those reported for other preparations (O'Brien and Fischbach, 1986; Vlachovà et al., 1987). Although this indicates that our experiments used pharmacologically relevant concentrations of agonists, the exact affinities of the several EAAs for either their specific or each other's receptors are still unknown. Thus, if kainate, at the concentrations used, displaced NMDA from its specific binding sites without substantially activating the large conductance states, PCP or MK-801 might not have been able to block an ionophore common to both kainate and NMDA (these antagonists are presumed to bind only after NMDA binds). Alternatively, kainate might have induced a response via a putative shared ionophore by displacing the antagonists PCP or MK-801 (perhaps by inducing a conformational change in the receptor molecule). We attempted to examine this possibility by using 2 different concentrations of kainate in the composition of drugs applied and found no dependence on concentration (Fig. 9). Thus, since a displacement of the antagonist by kainate does not occur, our results further support the notion that separate ionophores are responsible for the kainate- and NMDA-induced responses.

If, however, the different EAA receptors are, in truth, not coupled to separate channel proteins but exist as a single macromolecular assembly, a possible explanation for our findings might be that the antagonists MK-801 and PCP block only the large conducting state but not the smaller states. If this were the case, kainate would still activate a substantial current in the presence of the antagonists and NMDA. Another possibility would be the differential expression of receptor subunits, possibly via posttranslational modifications of the receptor-ionophore complex. That is, the putative EAA receptor entity in retinal ganglion cclls could sometimcs bc incomplctcly cxpressed. For example, the receptors of a given receptor-channel complex might lack either one of the agonist-specific binding sites. This possibility could account for the distribution of the magnitudes of kainate and NMDA responses (Fig. 1C) and an MK-801 and PCP inhibition of NMDA responses that does not affect the kainate-activated conductances (Figs. 8, 9). Such a molecular arrangement would likely be detected in experiments similar to those of Jahr and Stevens (1987) and Cull-Candy and Usowicz (1987), where NMDA would, in some instances, not activate channels in a patch in which kainate was effective. In retinal ganglion cells, with a calculated number of NMDA-activated channels per cell between 0 and 30 , the probability of finding a patch with such a channel was unfortunately extremely low. Thus, it was not possible to examine our preparation under these criteria to determine whether EAA receptors in cultured retinal ganglion cells are different than those in other preparations in this respect. Even if this were the case, our data indicate that not all of the functional EAA receptors are inexorably linked to a shared ionophore, since at least some receptor-channel complexes would be missing specific EAA recognition sites.

What do the EAA responses mean in terms of retinal physiology? The physiological dichotomy of the ON/OFF centersurround organization of ganglion cell receptive fields appears to be formed proximally in the retina, at the level of horizontal, amacrine, and bipolar cells (Nelson et al., 1981; Schiller, 1982; Sterling, 1983). Thus, it is unlikely that EAA receptors on ganglion cells contribute to this aspect of their responses. Nevertheless, EAA receptors are present on all second- and third-order neurons and appear to play a major role in synaptic transmission in the inner and outer plexiform layers. Responses to kainate appear to mimic the effect of light on ganglion cells, at least in some mammalian species (Massey and Miller, 1985). In contrast, the blockade of NMDA receptors by specific antagonists does not significantly affect the light response (Slaughter and Miller, 1983; Massey, 1987). Our present observations, together with those presented earlier, which show a small contribution of NMDA to the EAA response of rat retinal ganglion cells (Aizenman et al., 1988), confirm the reports that NMDA receptors might play a minor and subordinate role in mediating information-processing at the level of the ganglion cells as compared to kainate receptors.

Note added in proof: After submission of our manuscript, another paper appeared (MacDonald et al., 1987) that showed that ketamine blocks NMDA- but not kainate-induced currents in mouse hippocampal neurons. Moreover, the blockade of NMDA-gated channels by this antagonist had no effect on subsequent responses to kainate. These findings are consistent with our results and suggest that the kainate and NMDA receptors are coupled to distinct ionophores.

\section{References}

Aizenman, E., M. P. Frosch, and S. A. Lipton (1988) Responses mediated by excitatory amino acid receptors in solitary retinal ganglion cells from rat. J. Physiol. (Lond.) 396: 75-91.

Ariel, M., E. Lasater, S. Mangel, and J. E. Dowling (1984) On the sensitivity of $\mathrm{H} 1$ horizontal cells of the carp retina to glutamate, aspartate, and their agonists. Brain Res. 295: 179-183.

Ascher, P., and L. Nowak (1987) Electrophysiological studies of NMDA receptors. Trends Neurosci. 10: 284-288.

Ascher, P., W. A. Large, and H. P. Rang (1979) Studies on the mechanism of action of acetylcholine antagonists on rat parasympathetic ganglion cells. J. Physiol. (Lond.) 295: 139-170.

Ault, B., R. H. Evans, A. A. Francis, D. J. Oakes, and J. C. Watkins (1980) Selective depression of excitatory amino-acid induced depolarization by magnesium ions in isolated spinal cord preparations. J. Physiol. (Lond.) 307: 413-428.

Berger, S. J., M. L. McDaniel, J. G. Carter, and O. H. Lowry (1977) Distribution of four potential transmitter amino acids in monkey retina. J. Neurochem. 28: 159-163.

Bloomfield, S. A., and J. E. Dowling (1985a) Roles of aspartate and glutamate in synaptic transmission in rabbit retina. I. Outer plexiform layer. J. Neurophysiol. 53: 699-713.

Bloomfield, S. A., and J. E. Dowling (1985b) Roles of aspartate and glutamate in synaptic transmission in rabbit retina. II. Inner plexiform layer. J. Neurophysiol. 53: 714-725.

Clineschmidt, B. V., G. E. Martin, and P. R. Bunting (1982) Anticonvulsant activity of (+)-5-methyl-10,11-dihydro- 5 H-dibenzo[a,d]cyclohepten-5,10-imine (MK-801), a substance with potent anticonvulsant, central sympathomimetic, and apparent anxiolytic properties. Drug Dev. Res. 2: 123-134.

Cull-Candy, S. G., and M. M. Usowicz (1987) Multiple-conductance channels activated by excitatory amino acids in cerebellar neurons. Nature 325: 525-528.

Dräger, U. C., and A. Hofbauer (1984) Antibodies to heavy neurofilament subunit detect a subpopulation of damaged ganglion cells in retina. Nature 309: 624-626.

Fenwick, E. M., A. Marty, and E. Neher (1982) A patch-clamp study of bovine chromaffin cells and their sensitivity to acetylcholine. J. Physiol. (Lond.) 331: 577-597.

Fonnum, F. (1984) Glutamate: A neurotransmitter in mammalian brain. J. Neurochem. 42: 1-11.

Foster, A. C., and G. E. Fagg (1984) Acidic amino acid binding sites in mammalian neuronal membranes: Their characteristics and relationship to synaptic receptors. Brain Res. Rev. 7: 103-164.

Foster, A. C., and E. H. F. Wong (1987) The novel anticonvulsant 
MK-801 binds to the activated state of the $N$-methyl-D-aspartate receptor in rat brain. Br. J. Pharmacol. 91: 403-409.

Hamill, O. P., A. Marty, E. Neher, B. Sakmann, and F. J. Sigworth (1981) Improved patch-clamp technique for high resolution current recording from cells and cell-free membrane patches. Pfluegers Arch. 391: $85-100$.

Hille, B. (1984) Ionic Channels of Excitable Membranes, Sinauer, Sunderland, MA.

Honey, C. R., Z. Miljkovic, and J. F. MacDonald (1985) Ketamine and phencyclidine cause a voltage-dependent block of responses to L-aspartic acid. Neurosci. Lett. 61: 135-139.

Ikeda, H., and M. J. Sheardown (1982) Aspartate may be an excitatory transmitter mediating visual excitation of "sustained" but not "transient" cells in the cat retina: Iontophoretic studies in vivo. Neuroscience $7: 25-36$.

Ishida, A. T., and J. Neyton (1985) Quisqualate and L-glutamate inhibit retinal horizontal-cell responses to kainate. Proc. Natl. Acad. Sci. USA 82: 1837-1841.

Ishida, A. T., A. Kaneko, and M. Tachibana (1984) Responses of solitary retinal horizontal cells from Carassius auratus to L-glutamate and related amino acids. J. Physiol. (Lond.) 348: 255-270.

Jahr, C. E., and C. F. Stevens (1987) Glutamate activates multiple single channel conductances in hippocampal neurons. Nature 325 : $522-525$.

Johnson, J. L. (1972) Glutamic acid as a synaptic transmitter in the nervous system. A review. Brain Res. 37: 1-19.

Karschin, A., E. Aizenman, and S. A. Lipton (1987) NMDA and kainate interaction at the excitatory amino acid receptors in isolated rat retinal ganglion cells: Effects of phencyclidine and MK-801. Soc. Neurosci. Abstr. 13: 1555.

Kemp, J. A., T. Priestley, and G. N. Woodruff (1986) MK-801, a novel, orally active anticonvulsant, is a potent, non-competitive $N$-methyl-D-aspartate-receptor antagonist. Br. J. Pharmacol. (Suppl.) 89: 535P.

Lasater, E. M., and J. E. Dowling (1982) Carp horizontal cells in culture respond selectively to L-glutamate and its agonists. Proc. Natl. Acad. Sci. USA 79: 936-940.

Leifer, D., S. A. Lipton, C. J. Barnstable, and R. H. Masland (1984) Monoclonal antibody to Thy-1 enhances regeneration of processes by rat retinal ganglion cells in culture. Science 224: 303-306.

Lipton, S. A., and D. L. Tauck (1987) Voltage-dependent conductances of solitary ganglion cells dissociated from the rat retina. J. Physiol. (I ond.) 385: 361-391.

Lipton, S. A., E. Aizenman, and R. H. Loring (1987) Neural nicotinic acetylcholine responses in solitary mammalian retinal ganglion cells. Pfluegers Arch. 410: 37-43.

MacDermott, A. B., M. L. Mayer, G. L. Westbrook, S. J. Smith, and J. L. Barker (1986) NMDA-receptor activation increases cytoplasmic calcium concentration in cultured spinal cord neurons. Nature 321: $519-522$

MacDonald, J. F., Z. Miljkovic, and P. Pennefather (1987) Use-dependent block of excitatory amino acid currents in cultured neurons by ketamine. J. Neurophysiol. 58: 251-266.

Massey, S. C. (1987) NMDA receptors of rabbit ganglion cells. Inv. Ophthalmol. Vis. Sci. (Suppl.) 28: 405.
Massey, S. C., and R. F. Miller (1985) Differing effects of glutamate analogs and antagonists in the rabbit retina. Soc. Neurosci. Abstr. 11: 823.

Mayer, M. L. (1987) Two channels reduced to one. Nature 325: 480.

Mayer, M. L., and G. L. Westbrook (1985) The action of $N$-methyl$\mathrm{D}$-aspartic acid on mouse spinal neurones in culture. J. Physiol. (Lond.) 361: $65-90$

Migani, P., M. Virgili, A. Contestabile, A. Poli, L. Villani, and O. Barnabei (1985) $\left[{ }^{3} \mathrm{H}\right]$ Kainic acid binding sites in the synaptosomalmitochondrial (P2) fraction from goldfish brain. Brain Res. 361: 3645.

Miller, R. F., and M. M. Slaughter (1986) Excitatory amino acid receptors of the retina: Diversity of subtypes and conductance mechanisms. Trends Neurosci. 9: 211-218.

Murakami, M., T. Ohtsuka, and H. Shimazaki (1975) Effects of aspartate and glutamate on the bipolar cells in the carp retina. Vision Res. 15: 456-458.

Nelson, R., H. Kolb, M. M. Robinson, and A. P. Mariani (1981) Neural circuity of the cat retina: Cone pathways to ganglion cells. Vision Res. 21: 1527-1536.

Nowak, L., P. Bregestovski, P. Ascher, A. Herbert, and A. Prochiantz (1984) Magnesium gates glutamate-activated channels in mouse central neurones. Nature $307: 462-465$.

O'Brien, R. J., and G. D. Fischbach (1986) Characterization of excitatory amino acid receptors expressed by embryonic chick motoneurons in vitro. J. Neurosci. 6: 3275-3283.

O'Dell, T. J., and B. N. Christensen (1986a) N-Methyl-D-aspartate receptors coexist with kainate and quisqualate receptors on single isolated catfish horizontal cells. Brain Res. $381: 359-362$.

O'Dell, T. J., and B. N. Christensen (1986b) The action and interaction and some analogues on enzymatically isolated catfish horizontal cells. In Retinal Signal Systems. Degenerations and Transplants, E. Agardh and B. Ehinger, eds., pp. 151-161, Elsevier, New York.

Perry, V. H. (1979) The ganglion cell layer of the retina of the rat: A Golgi study. Proc. R. Soc. [Biol.] 204: 363-375.

Rang, H. P. (1981) Drugs and ionic channels: Mechanisms and implications. Postgrad. Med. J. 57: 89-97.

Rothman, S. M., and J. W. Olney (1987) Excitotoxicity and the NMDA receptor. Trends Neurosci. 10: 299-302.

Schiller, P. H. (1982) Central connections of the retinal ON and OFF pathways. Nature 297: 580-583.

Slaughter, M. M., and R. F. Miller. (1983) The role of excitatory amino acid transmitters in the mudpuppy retina: An analysis with kainic acid and $N$-methyl-D-aspartate. J. Neurosci. 3: 1701-1711.

Sterling, P. (1983) Microcircuitry of the cat retina. Annu. Rev. Neurosci. $6: 149-185$.

Vlachovà, L., L. Vyklicky, L. Vyklicky, Jr., and F. Vyskocil (1987) The action of excitatory amino acids on chick spinal cord neurons in culture. J. Physiol. (Lond.) 386: 425-438.

Watkins, J. C., and R. H. Evans (1981) Excitatory amino acid transmitters. Annu. Rev. Pharmacol. Toxicol. 21: 165-204.

Wong, E. H. F., J. A. Kemp, T. Priestley, A. R. Knight, G. N. Woodruft, and L. L. Iversen (1986) The anticonvulsant MK-801 is a potent $\mathrm{N}$-methyl-D-aspartate antagonist. Proc. Natl. Acad. Sci. USA 83: 7104 7108 . 